\title{
Rapid, Coordinate Inflammatory Responses after Experimental Febrile Status Epilepticus: Implications for Epileptogenesis
}

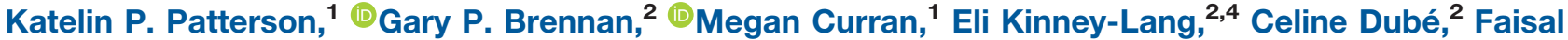 \\ Rashid, ${ }^{4}$ Catherine Ly, ${ }^{1}$ Andre Obenaus, ${ }^{4}$ and Tallie Z. Baram ${ }^{1,2,3}$
}

DOI:http://dx.doi.org/10.1523/ENEURO.0034-15.2015

${ }^{1}$ Department of Anatomy/Neurobiology, University of California-Irvine, Irvine, California 92697, ${ }^{2}$ Department of Pediatrics, University of California-Irvine, Irvine, California 92697, ${ }^{3}$ Department of Neurology, University of CaliforniaIrvine, Irvine, California 92697, ${ }^{4}$ Department of Radiation Medicine and Department of Pediatrics, Loma Linda University School of Medicine, Loma Linda, California 92350

\begin{abstract}
Epilepsy is a common neurological disorder with many causes. For temporal lobe epilepsy, antecedent insults are typically found. These risk factors include trauma or history of long fever-associated seizures (febrile status epilepticus) in childhood. Whereas the mechanisms by which such insults promote temporal lobe epilepsy are unknown, an extensive body of work has implicated inflammation and inflammatory mediators in both human and animal models of the disorder. However, direct evidence for an epileptogenic role for inflammation is lacking. Here we capitalized on a model where only a subgroup of insult-experiencing rodents develops epilepsy. We reasoned that if inflammation was important for generating epilepsy, then early inflammation should be more prominent in individuals destined to become epileptic compared with those that will not become epileptic. In addition, the molecular and temporal profile of inflammatory mediators would provide insights into which inflammatory pathways might be involved in the disease process. We examined inflammatory profiles in hippocampus and amygdala of individual rats and correlated them with a concurrent noninvasive, amygdalar magnetic resonance imaging epilepsy-predictive marker. We found significant individual variability in the expression of several important inflammatory mediators, but not in others. Of interest, a higher expression of a subset of hippocampal and amygdalar inflammatory markers within the first few hours following an insult correlated with the epilepsypredictive signal. These findings suggest that some components of the inflammatory gene network might contribute to the process by which insults promote the development of temporal lobe epilepsy.
\end{abstract}

Key words: biomarker; cytokine; epilepsy; febrile seizures; heterogeneity; magnetic resonance imaging

\section{Significance Statement}

Epilepsy is a devastating brain disorder affecting $\sim 1 \%$ of the world population. Epilepsy may arise because of genetic factors or may follow an insult or inciting event. A common antecedent of limbic, temporal-lobe epilepsy is a history of long febrile seizures in childhood. However, for unknown reasons, epilepsy develops only in some individuals who have experienced these early-life seizures. In our immature rat model of long febrile seizures, as in children, only some individuals progress to epilepsy, enabling us to address the mechanisms for these divergent outcomes. Here we find that a robust activation of some inflammatory mediators distinguishes individual rats that develop a predictive marker of epilepsy from those who do not. 


\section{Introduction}

Epilepsy is a common neurological disorder with many causes. For temporal lobe epilepsy, an adult epilepsy associated with cognitive and emotional deficits, antecedent insults are typically found. These risk factors include trauma or history of long fever-associated seizures in childhood (Cendes et al., 1993; French et al., 1993; Dubé et al., 2007).

Febrile status epilepticus (FSE) denotes long seizures (>30 min) associated with fever in early childhood (Berg and Shinnar, 1996; Berg et al., 1997). Mounting evidence suggests that FSE leads to temporal lobe epilepsy (TLE) in a subset of individuals (Annegers et al., 1987; Cendes et al., 1993; Dubé et al., 2007; Lewis et al., 2014; Seinfeld et al., 2014). Discerning the epileptogenic features of FSE has remained elusive, because in both human models (VanLandingham et al., 1998; Scott et al., 2002; Seinfeld et al., 2014) and rodent models (Toth et al., 1998, Dubé et al., 2004; Jansen et al., 2008; Hellier et al, 1998) there is evidence for neuronal stress and injury, but not for cell death, so that the epileptogenesis cannot be attributed simply to brain damage. To uncover the potential mechanisms by which FSE promotes epilepsy, several immature rodent models of FSE have been established and characterized (Baram et al., 1997; Heida et al., 2004; Dubé et al., 2010, 2000). In the model used here, $\sim 40 \%$ of rats exposed to early life experimental FSE (eFSE) go on to become epileptic. This fact enables a comparison of rats that become epileptic to those that do not, allowing for the dissection of processes essential for epileptogenesis (which leads to TLE) and processes that simply change during or after insult but do not contribute to the resulting epilepsy (Patterson et al., 2014).

Inflammation has been implicated in many animal models of acquired epilepsy, although its role in epileptogenesis remains unclear (Holtman et al., 2009, 2010; Vezzani et al., 2011, 2008). Fever, the initiator of FSE, intrinsically involves inflammation and the cytokine interleukin (IL)-1 $\beta$ is a crucial component in eFSE generation (Dubé et al., 2005). Further, higher levels of IL-1 $\beta$ are found in the hippocampus of animals that become epileptic (Luheshi

Received April 15, 2015; accepted September 28, 2015; First published October 8, 2015.

Authors declare no competing financial interests.

Author Contributions: K.P.P. and T.Z.B. designed research; K.P.P., G.P.B., M.C., E.K.-L., C.B., F.R., C.L., and A.O. performed research; K.P.P., G.P.B., M.C., E.K.-L., F.R., A.O., and T.Z.B. analyzed data; K.P.P. and T.Z.B. wrote the paper.

This work was supported by National Institutes of Health Grants R37/RO1NS-35439, T32-NS-45540, P20NS080185, and R01-NS-78279, and an American Epilepsy Society/Epilepsy Foundation of America Predoctoral Fellowship to K.P.P.

Acknowledgement: We thank Drs. Annamaria Vezzani, PhD, and Teresa Ravizza, $\mathrm{PhD}$, for their helpful comments on an earlier version of this manuscript.

Correspondence should be addressed to Tallie Z. Baram, Department of Anatomy/Neurobiology, University of California-Irvine, Irvine, CA 92697. Email: tallie@uci.edu.

DOI:http://dx.doi.org/10.1523/ENEURO.0034-15.2015

Copyright (C) 2015 Patterson et al.

This is an open-access article distributed under the terms of the Creative Commons Attribution 4.0 International, which permits unrestricted use, distribution and reproduction in any medium provided that the original work is properly attributed. et al., 1997; Dubé et al., 2005, 2010; Heida and Pittman,2005; Heida et al., 2009; Riazi et al., 2010; Eskilsson et al., 2014; Ravizza et al, 2008) .

For these reasons, inflammation has become an attractive target for antiepileptogenic therapies (De Simoni et al., 2000; Ollikainen et al., 2004; Dedeurwerdere et al., 2012; Pouliot et al., 2013). The goal of such interventions would be to abort the epileptogenic process before spontaneous seizures begin (Vezzani et al., 2011; Patterson et al., 2014). However, several important pieces of information are lacking, impeding our ability to implicate inflammation in the processes that follow both eFSE and human FSE that may promote epilepsy. First, it is not known which of the many potential inflammatory mediators are activated by eFSE, and the time courses of their augmented expression have not been delineated. Second, it is unknown whether variations in the inflammatory response take place in individual animals that might contribute to the eventual development of epilepsy in a subset of animals.

Answering these important questions has recently been facilitated by the discovery of an early, predictive, noninvasive marker of epileptogenesis. On a high-field MRI, reduction of $\mathrm{T} 2$ relaxation times throughout the limbic circuit, and especially in the basolateral amygdala, within hours after eFSE predicted epilepsy in later life (Choy et al., 2014). Further, T2 signal changes correlated to an early inflammatory process in the amygdala, the translocation of high-mobility group box 1 (HMGB1). HMGB1, classically thought of as a nuclear scaffolding protein, translocates out of the nucleus during cellular stress and is then released from the cell. It acts as a proinflammatory cytokine by binding to toll-like receptor 4 (TLR4), among others, to promote an inflammatory response (Bianchi and Manfredi, 2007; Maroso et al., 2010).

Here, we probed important questions about the relationship of inflammatory cascades provoked by eFSE and their implications for epileptogenesis. Specifically, we sought to (1) delineate the temporal course of specific components of the inflammatory response in the hours and days after eFSE; (2) investigate whether and how these inflammatory mediators vary among individual animals after eFSE; and (3) correlate the variation found in inflammatory mediators in hippocampus and amygdala to the variation found in MRI signal changes. Together, these studies further our understanding of post-eFSE inflammation and how this intricate set of molecules and processes may contribute to epileptogenesis.

\section{Materials and Methods}

\section{Experimental overview}

To characterize the spectrum of inflammatory changes provoked by eFSE, we induced experimental seizures, then conducted quantitative mRNA analyses at several time points, buttressed by Western blot analyses and immunocytochemistry. We focused on the hippocampal formation, which is involved in both eFSE and the subsequent epileptogenesis, as well as on the amygdala, the location of the epilepsy-predicting MRI signal change. mRNA analyses were performed at multiple time points, 
Table 1: Primer sequences used for RT-PCR

\begin{tabular}{|c|c|c|c|}
\hline Figure & Data structure & Type of test & Power \\
\hline 2D; CA1 Total cells & Normal distribution & Paired $t$ test & 0.4974 \\
\hline 2D; CA3 Total cells & Normal distribution & Paired $t$ test & 0.2679 \\
\hline $2 D$; hilus Total cells & Normal distribution & Paired $t$ test & 0.3565 \\
\hline 2D; CA1 percentage amoeboid & Normal distribution & Paired $t$ test & 0.0030 \\
\hline $2 D$; CA3 percentage amoeboid & Normal distribution & Paired $t$ test & 0.0040 \\
\hline $2 D ;$ hilus total cells & Normal distribution & Paired $t$ test & 0.0023 \\
\hline $2 E$ & Normal distribution & One-way ANOVA & 0.0016 \\
\hline $3 D ; \mathrm{CA} 1$ & Normal distribution & Paired $t$ test & $<0.0001$ \\
\hline $3 D ; \mathrm{CA} 3$ & Normal distribution & Paired $t$ test & $<0.0001$ \\
\hline $3 D$; hilus & Normal distribution & Paired $t$ test & 0.0023 \\
\hline $3 E$ & Normal distribution & One-way ANOVA & $<0.0001$ \\
\hline $4 E$ & Normal distribution & One-way ANOVA & 0.0027 \\
\hline 40 & Normal distribution & One-way ANOVA & 0.6696 \\
\hline $4 P$ & Normal distribution & One-way ANOVA & $<0.0001$ \\
\hline $5 A, B$ & Normal distribution & One-way ANOVA & 0.0010 \\
\hline $5 C$ & Normal distribution & One-way ANOVA & $<0.0001$ \\
\hline $5 D$ & Normal distribution & One-way ANOVA & 0.9015 \\
\hline $5 E$ & Normal distribution & One-way ANOVA & $<0.0001$ \\
\hline $5 F$ & Normal distribution & One-way ANOVA & 0.0064 \\
\hline $5 H$; GFAP & Normal distribution & Paired $t$ test & 0.0009 \\
\hline $5 H ;$ COX2 & Normal distribution & Paired $t$ test & 0.0044 \\
\hline $5 H ;$ IL-6 & Normal distribution & Paired $t$ test & 0.4225 \\
\hline $7 D$ & Normal distribution & Linear regression & 0.0016 \\
\hline $7 E$ & Non-Gaussian & Spearman $r$ & 0.0022 \\
\hline $7 E$ & Non-Gaussian & Spearman $r$ & 0.0011 \\
\hline $7 H$ & Non-Gaussian & Spearman $r$ & 0.0027 \\
\hline $7 I$ & Non-Gaussian & Spearman $r$ & 0.1541 \\
\hline
\end{tabular}

including 1, 3, 24, and $96 \mathrm{~h}$ after the end of the eFSE in hippocampus, and at $24 \mathrm{~h}$ in amygdala. Most immunocytochemistry as well as the hematoxylin and eosin staining was performed on tissue collected $24 \mathrm{~h}$ after the end of the eFSE (with additional time points for HMGB1).

\section{Induction of experimental febrile status epilepticus}

All animal procedures were performed in accordance with the regulations of the animal care committee of the University of California, Irvine. Postnatal day 10-11 SpragueDawley rat pups of both sexes were used for all studies. eFSE was achieved by inducing hyperthermia in pups. Pups were placed, two at a time, inside a $3 \mathrm{~L}$ flask, the bottom of which was lined with absorbent paper. Prior to hyperthermia, a glycerin-based hydrating ointment was applied to the paws, ears, and tail of the pups to mitigate potential hyperthermic skin injury. Pups were subjected to a continuous stream of warm air until behaviors indicating seizures began. These behaviors were identified as arrest of hyperthermiainduced hyperkinesis (freezing) followed by chewing automatisms. Core temperatures at the onset of these seizures were then rapidly measured, and seizure onset time was noted. Once seizures commenced, elevated core temperature and seizures were maintained via the warm air stream for $60 \mathrm{~min}$. Seizure behaviors typically progressed over the hyperthermia period, including chewing of an extremity, clonic movements, and eventual tonic extension. The core temperature of the pups was measured every 2 min during the eFSE. If the core temperature of the pups exceeded $41.5^{\circ} \mathrm{C}$, they were removed from the chamber and placed on a cool metal surface for the next 2 min. After $60 \mathrm{~min}$ of hyperthermia (typically 55-58 min of seizures), eFSE pups were gently and briefly immersed in cool water $\left(\sim 23.0^{\circ} \mathrm{C}\right)$ to aid in the return of core temperature to normothermia and to promote seizure cessation. Pups were then placed on a euthermic pad maintained at $37^{\circ} \mathrm{C}$ for $30 \mathrm{~min}$, and then were returned to their home cage and dam. In this study, all pups subjected to hyperthermia experienced eFSE, and there was no mortality.

\section{qRT-PCR Reverse transcription- PCR}

Whole hippocampi or amygdalae were rapidly dissected on ice at desired time points after the end of eFSE using RNAse-free instruments. Tissue was immediately transferred to prechilled centrifuge tubes kept on dry ice. Samples were stored at $-80^{\circ} \mathrm{C}$ until use. Total RNA was extracted from hippocampi using the mirVana miRNA Isolation Kit according to the manufacturer instructions (Ambion). Double-stranded cDNA was synthesized from total RNA using the First Strand cDNA Synthesis Kit (catalog \#04379012001; Roche) with random hexamer primers. Analysis of the PCR products was executed using cDNA samples in triplicate on a Lightcycler 96 System (Roche). Samples were normalized to $\beta$-actin and quantified using the cycle threshold method $\left(2^{\wedge} \Delta \Delta \mathrm{Ct}\right)$. Primers are provided in Table 1.

\section{Western blot}

Whole hippocampus from each hemisphere was dissected from rat brain $24 \mathrm{~h}$ post-FSE, and immediately flash frozen on dry ice and stored at $-80^{\circ} \mathrm{C}$ until use. Tissue was homogenized in a lysis buffer containing $0.01 \mathrm{~m}$ Tris- $\mathrm{HCl}$ and $1 \mathrm{~mm}$ EDTA. Proteins $(30 \mu \mathrm{g})$ were separated on either gradient gels $(8-12 \%)$ or $15 \%$ polyacrylamide SDS gels 

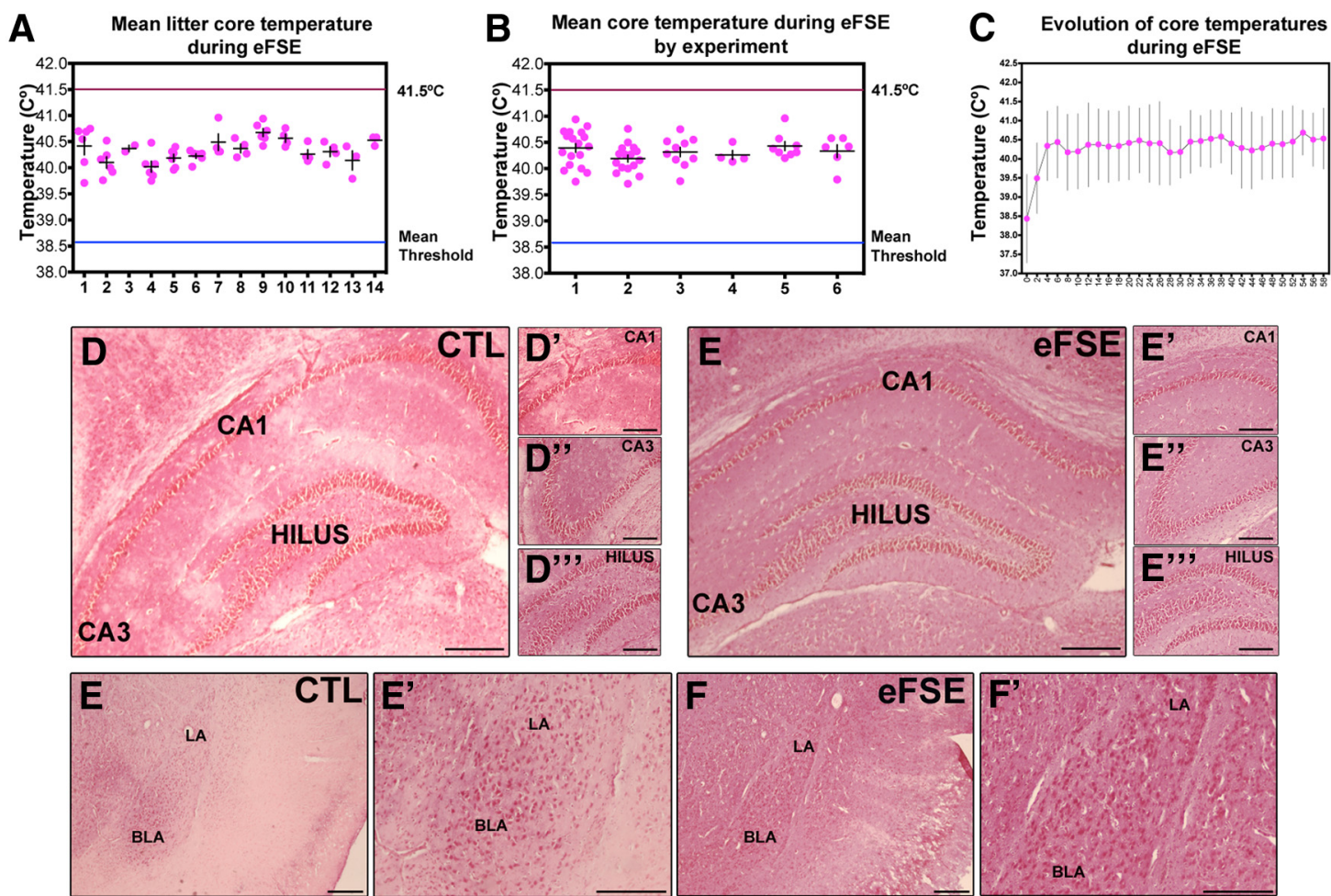

Figure 1. eFSE parameters. A, No statistical differences of mean core temperature exists between litters (or day of eFSE induction; $n=61$ over 14 litters). $\boldsymbol{B}$, eFSE data arranged by experimental group show no difference in mean core temperatures during eFSE ( $n=61$ experimental groups are distinguished with numbers $1-6$ on the $x$-axis). No animal used in this study had a mean core temperature during eFSE that exceeded $41.5^{\circ} \mathrm{C}$. $\boldsymbol{C}$, Elevated core temperatures after the first 2 min of eFSE were similar for the duration of eFSE $(n=61$ time of core temperature reading are delineated in 2 min epochs across the $x$-axis). No overt differences in structure or cell fallout were apparent $24 \mathrm{~h}$ after the end of eFSE in hippocampus or amygdala using H\&E staining (D-F'). CTL, Control. LA, lateral amygdala. BLA, basolateral amygdala.

(Lonza), transferred to PVDF membranes (GE Healthcare), and blocked with $5 \%$ whole milk. Membranes were then incubated with primary antibodies [GFAP 1:1000, Millipore; cyclooxygenase (Cox)-2 1:1000, Abcam; IL-6 1:2000, Abcam; and $\beta$-actin 1:20,000, Abcam] overnight at $4^{\circ} \mathrm{C}$. The next day, membranes were washed in PBS-T and then incubated with HRP-conjugated secondary antibodies for 1 $\mathrm{h}$ at room temperature. Excess secondary antibody was removed with repeated washes in PBS-T; then membranes were visualized by repeated ECL (Pierce) exposures of various lengths and nonsaturated blots were selected, and normalized to $\beta$-actin. Western blots were analyzed using ImageJ without the knowledge of the treatment group

\section{Immunocytochemistry}

Rats were deeply anesthetized with pentobarbital and transcardially perfused with $4 \%$ paraformaldehyde (PFA) at desired time points post-eFSE. Brains were removed and post-fixed in 4\% PFA for 90 min. Brains were then cryoprotected in $30 \%$ sucrose, rapidly frozen, and stored at $-80^{\circ} \mathrm{C}$. Thirty micrometer sections of dorsal hippocampus were obtained on a cryostat and stored in antifreeze at $4^{\circ} \mathrm{C}$ until use. Serial sections were blocked in $10 \%$ normal goat serum and $0.03 \%$ Triton $\mathrm{X}$ in $1 \times$ PBS for $1 \mathrm{~h}$ at $4^{\circ} \mathrm{C}$. Primary antibodies were incubated in $4 \%$ normal goat serum with $0.03 \%$ Triton $X$ overnight at $4^{\circ} \mathrm{C}$. The following antibodies were used: rabbit anti-HMGB1
1:1000 (Abcam), mouse anti-GFAP 1:3000 (Millipore), and mouse anti-IBA1 1:4000 (Wako). Sections were washed with $1 \times$ PBS, and the reaction product was visualized using 3,3'-diaminobezidine. Colocalization of cell markers with HMGB1 was achieved by coincubating rabbit antiHMGB1 1:1000 (Abcam) with the following antibodies: mouse anti-NeuN (Chemicon), mouse anti-GFAP 1:3000 (Millipore), and mouse anti-CD11b (ABD Serotec). After 24 $h$ of incubation, sections were washed in $1 \times$ PBS and then incubated in the appropriate secondary antibodies conjugated with Alexa Fluor 568 or Alexa Fluor 488. Colocalization was visualized using confocal microscopy.

\section{Hematoxylin and eosin staining}

Thirty micrometer coronal sections containing dorsal hippocampus and amygdala were obtained via cryostat and dried onto glass microscope slides. Sections were rinsed two to three times in distilled $\mathrm{H}_{2} \mathrm{O}$ and then placed in hematoxylin solution for 5 min (Poly Scientific Research). Slides were placed under running tap water until water was no longer colored with stain and then dunked two to three times in acid alcohol $(1 \% \mathrm{HCl}$ in $70 \% \mathrm{EtOH})$ until sections turned pink in color. After rinsing three to five times in tap water, sections were submerged five to six times in ammonia water $\left(1 \mathrm{ml}\right.$ of $\mathrm{NH}_{4} \mathrm{OH}$ in $1 \mathrm{~L}$ of $\left.\mathrm{H}_{2} \mathrm{O}\right)$ to darken sections. After rinsing sections for 3-5 min in tap water, slides were submerged in Eosin Y solutions (Poly Sci- 

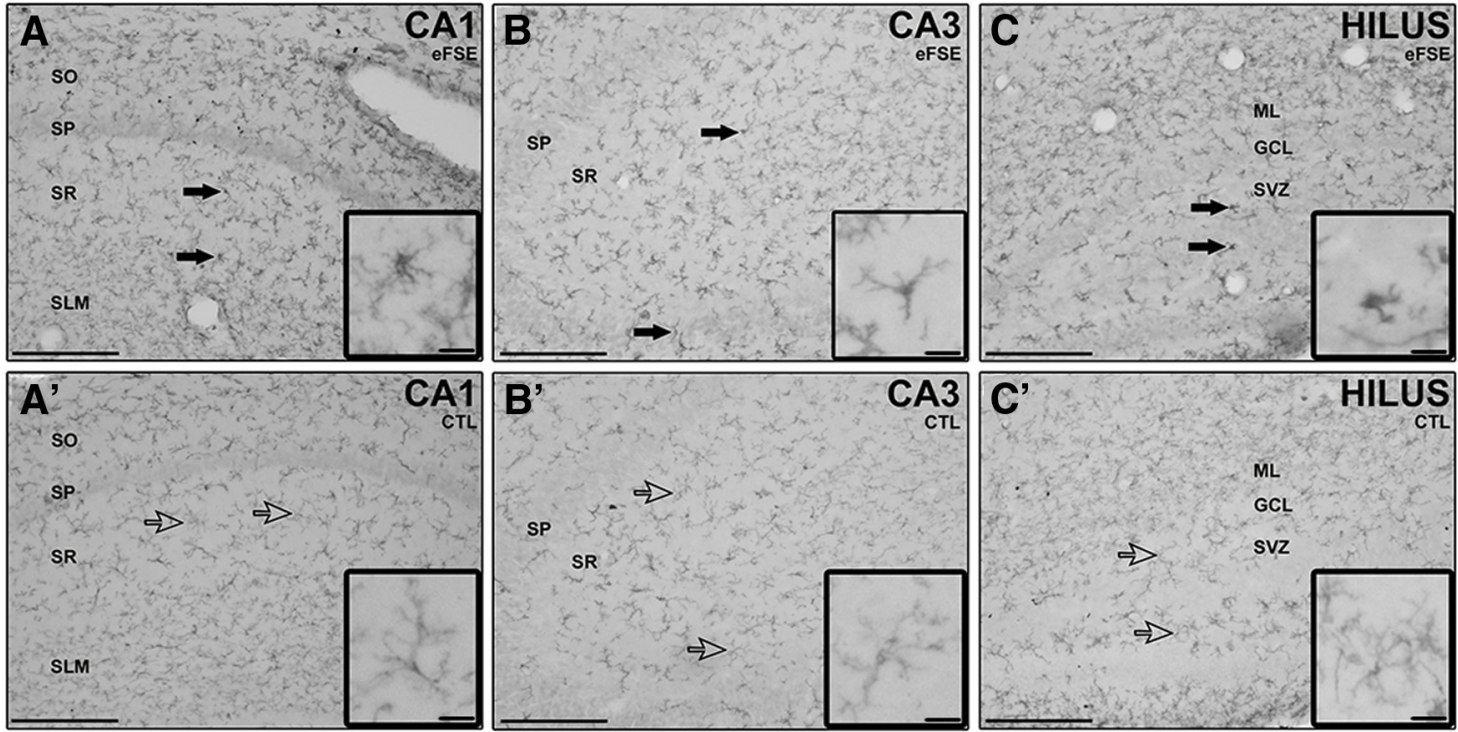

D

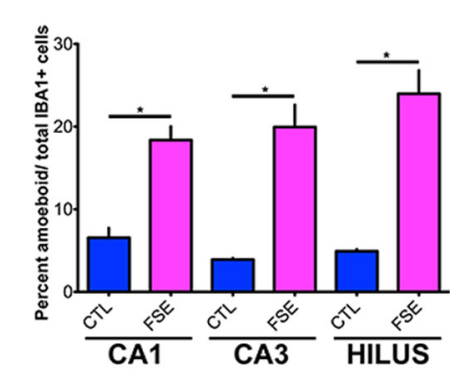

E
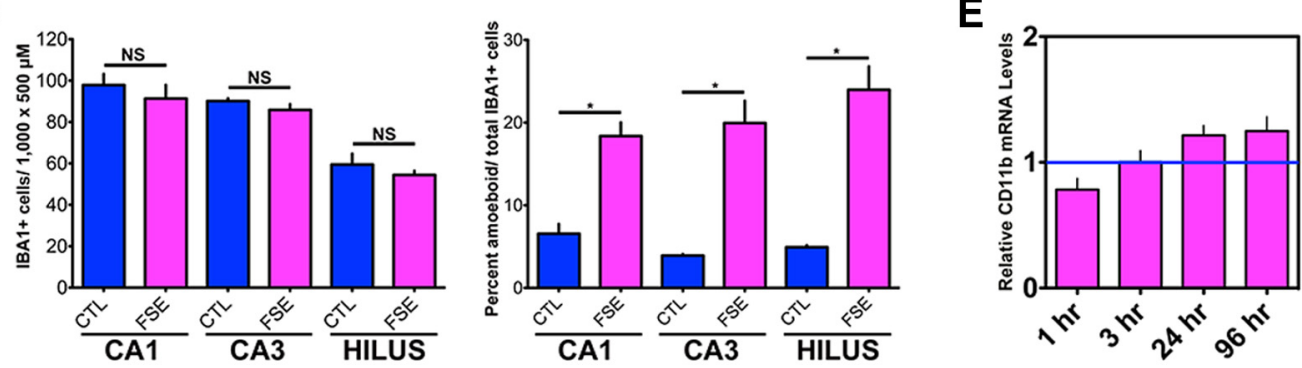

Figure 2. Activated microglia after eFSE. IBA1-IR cells are visible $24 \mathrm{~h}$ after eFSE in dorsal hippocampus in both eFSE rats $(\boldsymbol{A}, \boldsymbol{B}, \boldsymbol{C})$ and control rats $\left(\boldsymbol{A}^{\prime}, \boldsymbol{B}^{\prime}, \boldsymbol{C}^{\prime}\right)$. $\boldsymbol{D}$, While the number of IBA1-IR cells is similar between the eFSE group $(n=4)$ and control group $(n=$ 4), eFSE rats have a larger percentage of amoeboid microglia. Ramified (or nonactivated) microglia have slender, long processes with small soma, while amoeboid (or activated) microglia have short, thick processes with a distinct large soma. Solid arrows point to amoeboid microglia, while empty arrows point to ramified microglia. $\boldsymbol{E}$, There are no differences in mRNA levels for CD11b $(1 \mathrm{~h}, n=$ 5; $3 \mathrm{~h}, n=6 ; 24 \mathrm{~h}, n=6 ; 96 \mathrm{~h}, n=4)$, which can increase as microglia become active. Data are presented as the mean $\pm \mathrm{SEM}$. Scale bars: $\boldsymbol{A}-C^{\prime}, 200 \mu \mathrm{m}$; insets, $5 \mu \mathrm{m}$. *Statistically significant at $p<0.05$. CTL, Control. SO, stratum oriens. SP, stratum pyramidale. SR, stratum radiatum. SLM, lacunosum- moleculare. ML, molecular layer. GCL, granule cell layer. SVZ, subventricular zone.

entific Research) for 1 min and then rinsed again in tap water. Slides were dehydrated in ethanol and xylenes, coverslipped in paramount, and allowed to dry until analysis.

\section{Quantification of immunocytochemistry}

Quantification of activated microglia after eFSE in hippocampal CA1, CA3, and hilus was achieved by boxing off $1000 \times 500 \mu \mathrm{m}$ areas of each studied region. First, all IBA $1^{+}$cells in the defined region were counted and compared among groups. Activated microglia were identified as IBA $1^{+}$cells that had large, dark soma and few short processes that were thicker in appearance than nonactivated microglia (Lenz et al., 2013). Microglia activation is presented as the percentage change in activated microglia over the total number of IBA ${ }^{+}$cells. Quantification of $\mathrm{GFAP}^{+}$cells was achieved by using the same hippocampal regions and area delineations. GFAP ${ }^{+}$cells were counted and compared among groups. HMGB1 quantification was accomplished by counting all $\mathrm{HMGB} 1^{+}$cells in a $100 \times 500 \mu \mathrm{m}$ region of CA1. Translocation of HMGB1 protein was identified by the presence of immunoreactiv- ity outside the nucleus (i.e., in the somatic cytoplasm and in the processes of cells). Change in HMGB1 translocation is presented as the percentage change in translocated cells over the total number of $\mathrm{HMGB} 1^{+}$cells.

\section{MRI procedure and analysis}

MRls used a Bruker Avance 11.7 T MR scanner. Rats were anesthetized with $1.5 \%$ isoflurane in $100 \% \mathrm{O}_{2}$ and remained anesthetized for the duration of the scan. Their body temperature was maintained at $\sim 36.5^{\circ} \mathrm{C}$ via a warmwater cushion underneath them. A field-of-view of $2.3 \mathrm{~cm}$ and a slice thickness of $0.75 \mathrm{~mm}$ were used for scans. T2-weighted images were acquired using a 2D multi-echospin-echo sequence with the following parameters: TR, $4697 \mathrm{~ms}$; TE, 10.21-100.1 ms; inter-TE, $10.21 \mathrm{~ms}$; matrix size, $192 \times 192$; and number of averages, 2. Animals were imaged $6 \mathrm{~h}$ after the end of eFSE. Control and eFSE animals were intermixed to maximize the homogeneity of the imaging parameters. Images were coded and analyzed without knowledge of treatment group. Basal amygdalae were delineated manually and separately in the left and right hemi- 


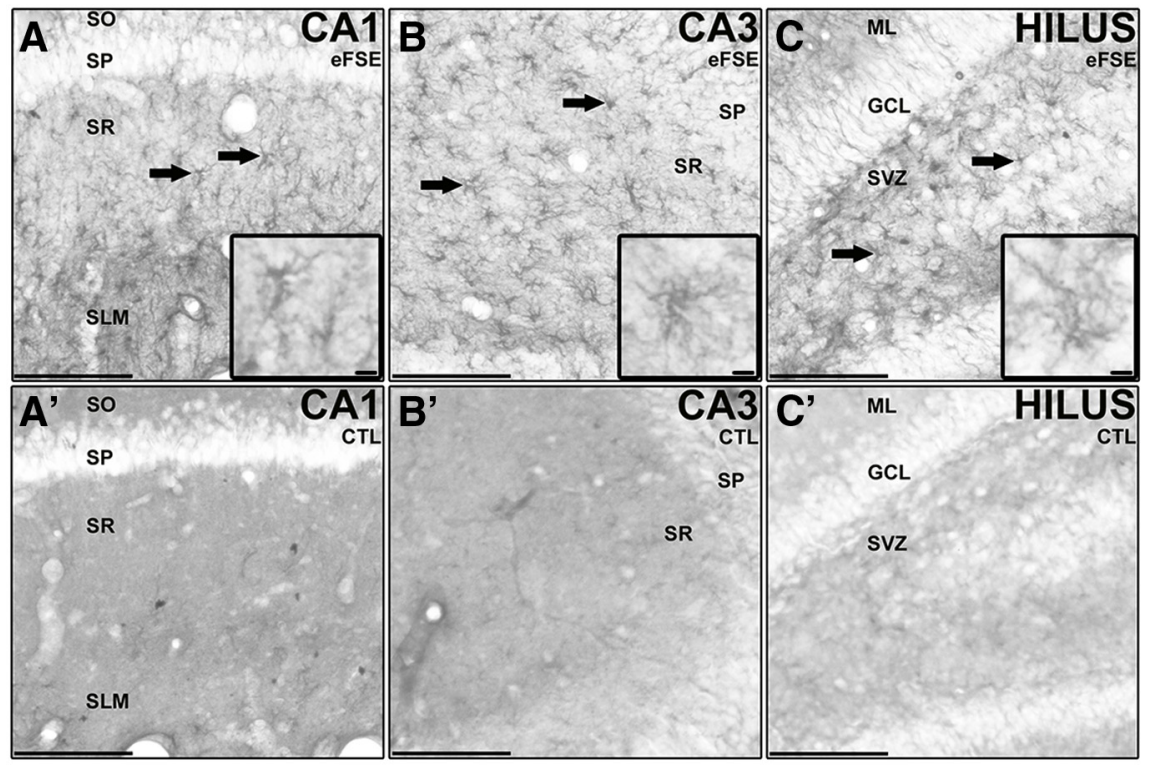

D

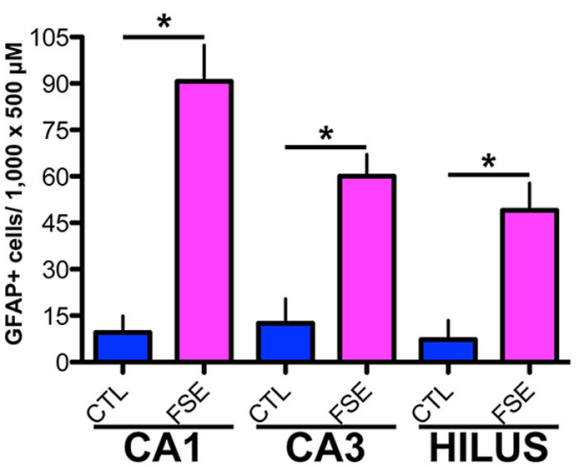

$\mathbf{E}$

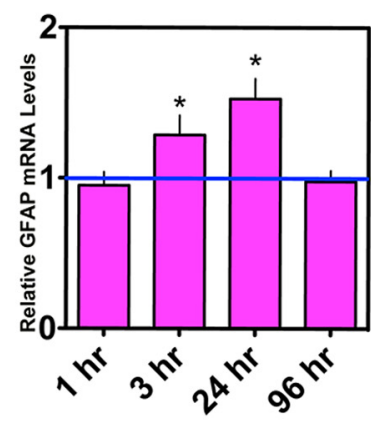

Figure 3. Activated astrocytes after eFSE. GFAP-IR cells are visible in dorsal hippocampus regions CA1, CA3, and the hilus of the dentate gyrus $24 \mathrm{~h}$ after eFSE $(\boldsymbol{A}, \boldsymbol{B}, \boldsymbol{C} ; n=4)$ but not in control rats $\left(\boldsymbol{A}^{\prime}, \boldsymbol{B}^{\prime}, \boldsymbol{C}^{\prime} ; n=4\right)$. Solid arrows depict $\mathrm{GFAP}^{+}$cells. $\boldsymbol{D}$, Quantification reveals a significant increase in the number of GFAP-IR cells compared with controls. $E$, mRNA levels of GFAP are significantly increased 3 and $24 \mathrm{~h}$ after eFSE, but not at 1 or $96 \mathrm{~h}$ ( $1 \mathrm{~h}, n=5 ; 3 \mathrm{~h}, n=6 ; 24 \mathrm{~h}, n=6$; $96 \mathrm{~h}, n=4)$. Data are presented as the mean \pm SEM. Scale bars: $\boldsymbol{A}-\boldsymbol{C}^{\prime}, 200 \mu \mathrm{m}$; insets, 5 $\mu \mathrm{m}$. *Statistically significant at $p<0.05$. CTL, Control. SO, stratum oriens. SP, stratum pyramidale. SR, stratum radiatum. SLM, lacunosummoleculare. ML, molecular layer. GCL, granule cell layer. SVZ, subventricular zone.

spheres. T2 values were measured using ImageJ software in which the images were defined on grayscale maps and a dynamic range of $1-100 \mathrm{~ms}$ was used. MRI signal changes are frequently unilateral both in children with FSE and in rodent models of FSE (Dubé et al., 2009b; Choy et al., 2014). Therefore, each amygdala was analyzed separately, and the side with the lower T2 relaxation time was used. The same approach was taken for the control rats, so that the amygdala with the lower T2 value was compared in all groups.

\section{Results}

\section{Description and parameters of the inciting eFSE}

All animals exposed to hyperthermia developed eFSE. Mean core temperatures did not significantly differ between litters or the experimental groups during 60 min of sustained eFSE (Fig. 1A,B). Further, mean core temperatures did not rise above $41.5^{\circ} \mathrm{C}$ in any animal, nor did they drop below the mean seizure threshold. In general, once seizures commenced (average, $3.9 \mathrm{~min}$; Dubé et al., 2007), core temperatures did not significantly change during the course of hyperthermia (Fig. 1C). Twenty-four hours after the end of eFSE, hematoxylin and eosin staining did not suggest overt neuronal staining or dropout in dorsal hippocampus or amygdala from rats experiencing eFSE (Fig. 1D-F'). These nonquantitative observations are in line with previous exhaustive quantitative analyses in several rat cohorts subjected to the same model and following the same duration of hyperthermia (Toth et al., 1998; Dubé et al., 2010)

\section{Activation of astrocytes and microglia in hippocampus after FSE}

The number of cells expressing the microglia marker IBA1 (Fig. $2 A-C^{\prime}$ ) was not different between the control and eFSE groups $24 \mathrm{~h}$ after the insult. However, there were changes in the shape of IBA1-immunoreactive (IR) cells between groups (Fig. 2D). In the control group, IBA1-IR cells had long pro- 

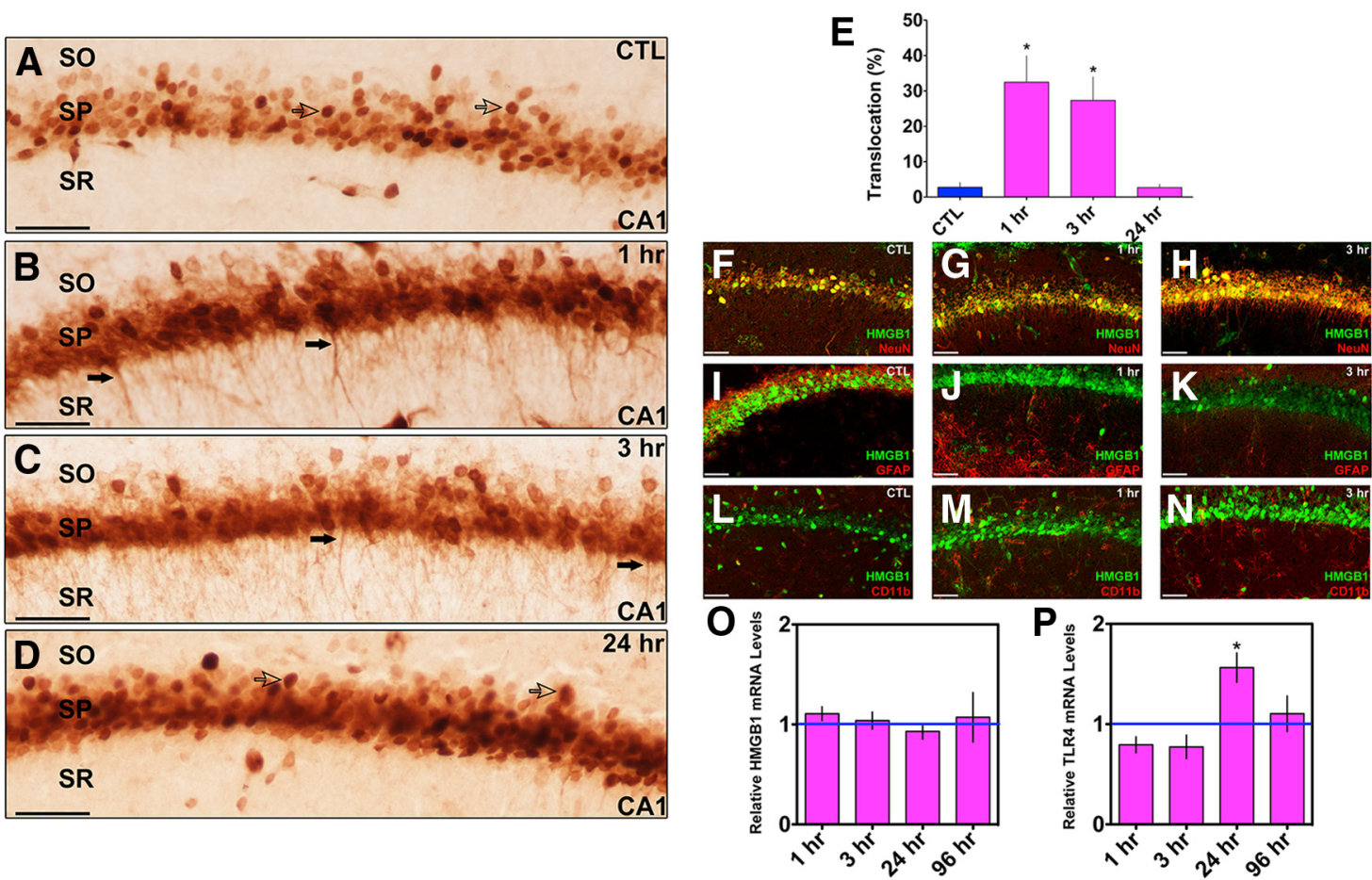

Figure 4. HMGB1 translocation in hippocampal neurons after eFSE. $\boldsymbol{A}$, In control animals $(n=3)$, HMGB1 is confined to the nucleus of cells (open arrows) in area CA1 of dorsal hippocampus. $\boldsymbol{B}$, One hour after the end of eFSE, HMGB1-IR is seen in the processes of neurons (closed arrows; $n=4)$, indicating translocation of HMGB1 from the nucleus. $\boldsymbol{C}$, Translocation is still evident $3 \mathrm{~h}$ after the end of eFSE $(n=4)$. $\boldsymbol{D}$, By $24 \mathrm{~h}$ after eFSE, mostly nuclear HMGB1 is observed $(n=4)$. $\boldsymbol{E}$, Quantification of HMGB1 immunocytochemistry as the percentage of HMGB1-IR cells with translocation over total HMGB1-IR cells shows a significant increase in the percentage of HMGB1 translocation 1 and $3 \mathrm{~h}$ after eFSE with a return to control conditions by $24 \mathrm{~h}$. $\boldsymbol{F}-\boldsymbol{M}$, Double labeling of HMGB1 and NeuN (both in soma and processes) demonstrates that HMGB1 translocation occurs from neurons $(\boldsymbol{F}-\boldsymbol{H})$ and not from astrocytes, as shown with GFAP $(\boldsymbol{I}-\boldsymbol{K})$, or microglia, as shown with $\mathrm{CD} 11 \mathrm{~b}(\mathbf{L}, \boldsymbol{M} ; \mathrm{CTL} n=3 ; 1 \mathrm{~h}, n=$ $4 ; 3 \mathrm{~h}, n=4)$. $O$, There is no increase in the levels of HMGB1 mRNA, indicating that translocation is achieved using already available protein (1 h, $n=5 ; 3 \mathrm{~h}, n=6 ; 24 \mathrm{~h}, n=6 ; 96 \mathrm{~h}, n=4)$. $\boldsymbol{P}$, TLR4, one receptor through which proinflammatory HMGB1 acts, mRNA is upregulated $24 \mathrm{~h}$ after eFSE with a return to baseline values by $96 \mathrm{~h}(1 \mathrm{~h}, n=5 ; 3 \mathrm{~h}, n=6 ; 24 \mathrm{~h}, n=6 ; 96 \mathrm{~h}, n=4)$. Data are presented as the mean $\pm \mathrm{SEM}$. Scale bars, $100 \mu \mathrm{m}$. *Statistically significant at $p<0.05$. CTL, Control. SO, stratum oriens. SP, stratum pyramidale. SR, stratum radiatum.

cesses, while many cells in the eFSE group had no processes or were more globular in shape (Fig. 2A-C'). IBA1-IR cells with long processes are regarded as ramified microglia (nonactivated), indicative of a quiescent state. Globular IBA1-IR cells with short or nonvisible processes are indicative of activated or amoeboid microglia (Lenz et al., 2013). Because activated microglia produce CD11b, we measured CD11b mRNA levels. There were no significant changes in the expression of this molecule in the post-eFSE hippocampus at any time point (Fig. 2E).

In hippocampi from rats killed $24 \mathrm{~h}$ following eFSE, the number of GFAP-IR cells increased compared with controls in hippocampal CA1, CA3, and the hilus of dentate gyrus (Fig. $3 A-D$ ). GFAP mRNA levels were increased at 3 and $24 \mathrm{~h}$ after eFSE, and returned to baseline levels at 96 $h$, as measured with RT-PCR reverse transcription- PCR (Fig. 3E). Together, these data indicate that GFAP production was increased in astrocytes after eFSE, which is consistent with the activation of this cell population.

\section{HMGB1 translocation in hippocampal neurons after eFSE}

Our previous studies demonstrated HMGB1 translocation from nuclei to cytoplasms of amygdala neurons in parallel with the appearance of T2 signal changes in the amygdala of the same rats. Here we focused on hippocampus, the origin of spontaneous seizures in rats that become epileptic after eFSE. HMGB1 was localized to the nuclei of cells in control CA1 neurons (Fig. $4 A$ ). At 1 and $3 \mathrm{~h}$ after eFSE, HMGB1-IR appeared in the cytoplasm, which is indicative of translocation of this protein (Fig. 4B,C). Cytoplasmic HMGB1 was no longer present $24 \mathrm{~h}$ after eFSE (Fig. 4E). HMGB1 colocalized with NeuN-IR hippocampal cells, but not with GFAP-IR or CD11b-IR cells (Fig. 4F-N). No changes in hippocampal HMGB1 mRNA levels were found at any of the examined time points (Fig. 4O). mRNA expression of one of the target molecules of HMGB1, TLR4, significantly increased at $24 \mathrm{~h}$ after eFSE (Fig. 4P) and was back at baseline levels $4 \mathrm{~d}$ after the eFSE. Together, these data suggest a rapid yet transient translocation of hippocampal HMGB1 from the nucleus to the cytoplasm, likely followed by secretion from the cell and activation of target receptors. This process took place in hippocampal neurons, but not in microglia or astrocytes.

\section{Cytokine expression after eFSE}

IL-1 $\beta$ mRNA levels increased significantly in hippocampus 1 and $3 \mathrm{~h}$ after eFSE. Levels then declined, so that, by 

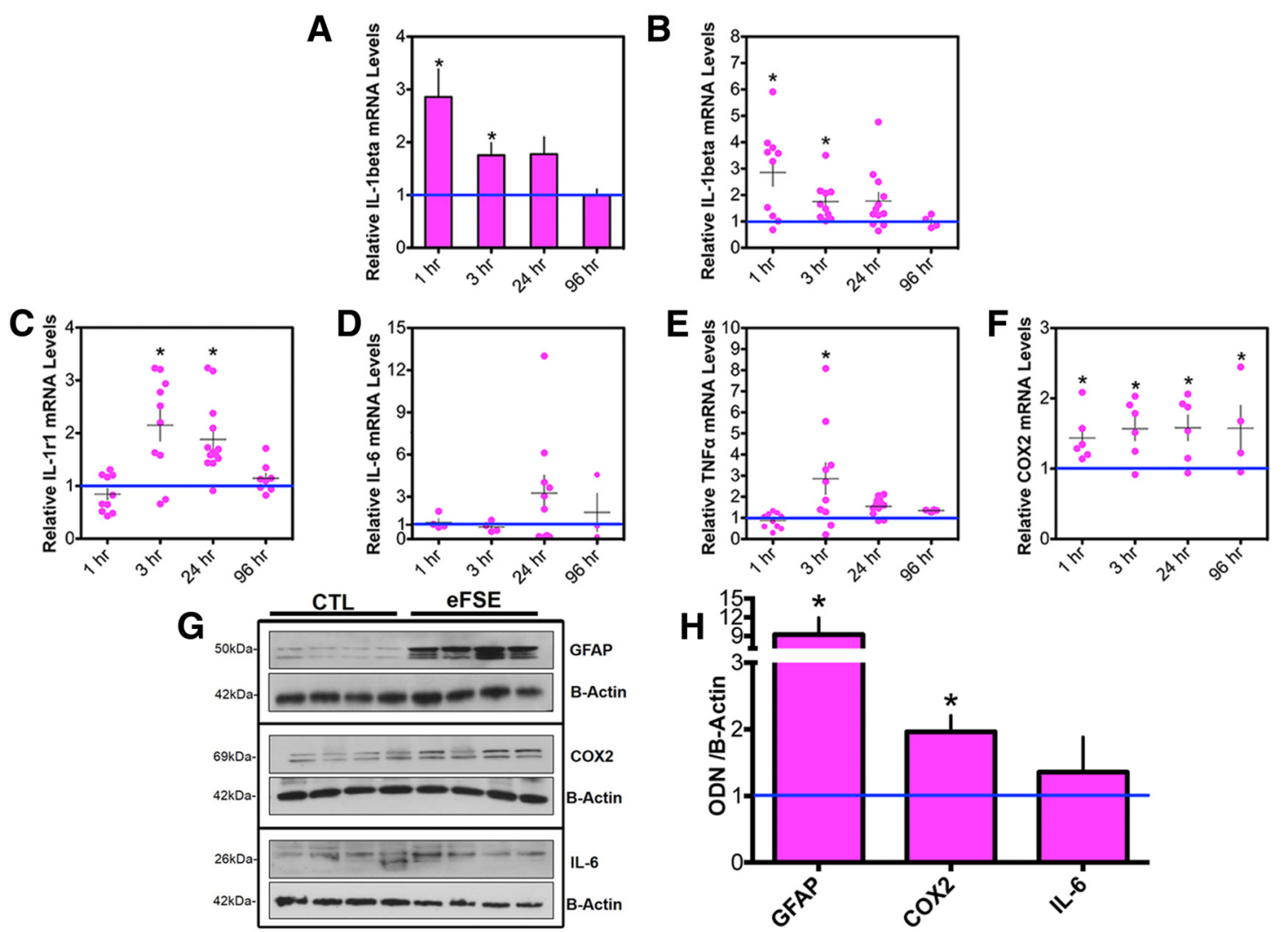

Figure 5. Transient cytokine upregulation after eFSE. $\boldsymbol{A}$, IL-1 $\beta$ mRNA levels are significantly upregulated 1 and $3 \mathrm{~h}$ after eFSE (CTL $=23 ; 1 \mathrm{~h}$, $n=10 ; 3 \mathrm{~h}, n=10 ; 24 \mathrm{~h}, n=12 ; 96 \mathrm{~h}, n=4)$. $\boldsymbol{B}$, Variability of IL-1 $\beta$ mRNA expression between rats is apparent when data are presented as individual animals where some rats have high levels of IL-1 $\beta$ expression and others are indistinguishable from controls. $\boldsymbol{C}$, IL-1r1 mRNA levels are significantly upregulated 3 and $24 \mathrm{~h}$ after eFSE, with obvious interanimal variability (CTL, $n=20$; $1 \mathrm{~h}, n=10 ; 3 \mathrm{~h}, n=10 ; 24 \mathrm{~h}, n=13 ; 96 \mathrm{~h}, n$ $=4)$. $D$, While never statistically significant, IL-6 levels trend upward for some animals at $24 \mathrm{~h}$ with a return to baseline values by $96 \mathrm{~h}$ (CTL, $n=$ $9 ; 1 \mathrm{~h}, n=4 ; 3 \mathrm{~h}, n=4 ; 24 \mathrm{~h}, n=10 ; 96 \mathrm{~h}, n=4)$. $E$, TNF- $\alpha$ mRNA levels are significantly augmented by $3 \mathrm{~h}$ and return to baseline by $24 \mathrm{~h}$ (CTL, $n=25 ; 1 \mathrm{~h}, n=10 ; 3 \mathrm{~h}, n=10 ; 24 \mathrm{~h}, n=12 ; 96 \mathrm{~h}, n=4)$. $\boldsymbol{F}$, COX2 mRNA levels are significantly upregulated at every tested time point (CTL, $n=11 ; 1 \mathrm{~h}, n=6 ; 3 \mathrm{~h}, n=6 ; 24 \mathrm{~h}, n=6 ; 96 \mathrm{~h}, n=4)$. G, GFAP, COX2, and IL-6 protein levels are augmented with interanimal variation $24 \mathrm{~h}$ after eFSE $(n=4)$ compared with littermate controls $(n=4)$. Densitometric analyses of protein levels normalized and compared with controls are provided in $\boldsymbol{H}$. Data are presented as the mean \pm SEM. *Statistically significant at $p<0.05$.

$96 \mathrm{~h}$ after eFSE, IL-1 $\beta$ mRNA levels were indistinguishable from those of control rats (Fig. $5 A$ ). Notably, there was a significant interanimal variability in the levels and temporal kinetics of IL-1 $\beta$ mRNA expression (Fig. 5B).

Interanimal variability was prominent upon examination of the time courses of expression of all other investigated cytokines. Levels of IL-1r1 mRNA (the IL-1 $\beta$ receptor) increased significantly 3 and $24 \mathrm{~h}$ after eFSE, and returned to baseline levels by $96 \mathrm{~h}$ (Fig. $5 \mathrm{C}$ ). No augmentation of IL-6 mRNA was found at 1 and $3 \mathrm{~h}$ after eFSE, but levels were increased by $24 \mathrm{~h}$ in a subset of rats and returned to baseline in all rats by $96 \mathrm{~h}$ (Fig. 5D). Hippocampal TNF- $\alpha$ mRNA was significantly augmented $3 \mathrm{~h}$ after eFSE and returned to baseline by $24 \mathrm{~h}$ (Fig. 5E). COX2 expression was significantly enhanced at all tested time points after eFSE and remained upregulated at $96 \mathrm{~h}$, the last time point assessed (Fig. 5F).

To examine whether augmented mRNA expression of cytokines translated into increased levels of functional inflammatory mediators, protein levels of GFAP, COX2, and IL-6 were measured in hippocampi $24 \mathrm{~h}$ after eFSE
(Fig. 5G,H). These specific proteins were chosen because of the upregulation of their mRNA $24 \mathrm{~h}$ after eFSE in some but not all rats. We found a significant increase in protein levels of COX2 and GFAP in hippocampus, with interanimal variability, which were similar to the findings at the mRNA level. Similar to mRNA levels, protein levels of IL-6, measured in hippocampus $24 \mathrm{~h}$ after eFSE, were not consistently or significantly increased.

\section{Distinct inflammatory cytokine profiles in individual rats after eFSE}

Following eFSE, $\sim 40 \%$ of rats develop epilepsy (Dubé et al., 2010; Choy et al., 2014). If inflammatory molecule activation contributes to epileptogenesis after eFSE, the prediction is that there will be strong individual variation in cytokine expression, with robust changes in $\sim 40 \%$ of rodents experiencing eFSE. We tested this possibility by delineating the inflammatory cytokine profile of individual rats.

The expression of different cytokines peaks at different time points; therefore, the time point for the maximal 
A

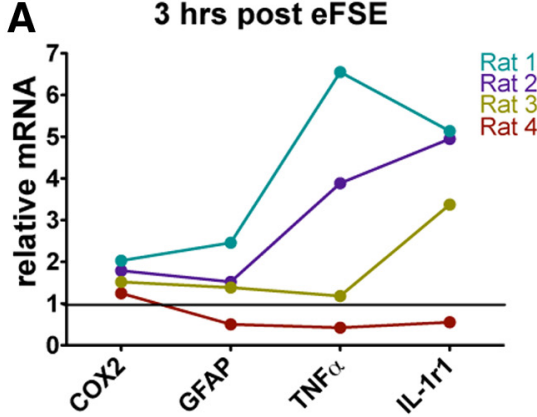

B 24 hrs post eFSE

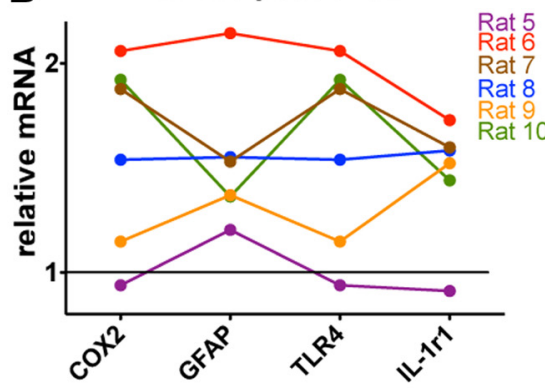

Figure 6. Interanimal variation of inflammatory mediator expression after eFSE. $\boldsymbol{A}$, Three hours after eFSE, COX2, GFAP, TNF- $\alpha$, and IL-1r1 levels were significantly increased. When the expression profile of an individual rat is examined across these mediators, trends in expression appear $(n=4)$. For example, rat 1 has the highest expression across all explored mediators, while rat 4 has virtually no inflammatory response after eFSE. Rats 2 and 3 both fall in between rats 1 and 4 , with moderate expression profiles. $\boldsymbol{B}$, A similar pattern is found $24 \mathrm{~h}$ after eFSE as well $(n=6)$. COX2, IL-1r1, TLR4, and GFAP were all significantly upregulated at this time point. As seen with the $3 \mathrm{~h}$ time point, rats with high expression in one mediator have high expression in all others, and vice versa. Rat 6 has the highest expression of all examined mediators, while Rat 5 is a nonresponder.

expression of each cytokine was included in the composite molecular profile of each rat experiencing eFSE (Fig. 6). By $3 \mathrm{~h}$ after the end of eFSE, mRNA levels of COX2, GFAP, TNF- $\alpha, \mathrm{IL}-1 \beta$, and IL-1r1 were significantly augmented (Fig. 6A). In individual animals, the expression levels of these cytokines tended to covary: animals with high expression of one cytokine tended to have higher expression of the others, whereas animals with low expression of one cytokine had depressed levels of the others. This trend was also found at the $24 \mathrm{~h}$ time point, when IL-1r1, COX2, and TLR4 were significantly upregulated in a subset of rats (Fig. 6B).

\section{Expression levels in hippocampus and amygdala of a subset of inflammatory mediators correlate with a predictive marker of post-eFSE epilepsy}

We previously investigated potential noninvasive predictive markers for the epileptogenesis that, in a subset of rats, follows eFSE. We found that decreased MRI T2 relaxation times in the amygdala 2-4 $\mathrm{h}$ after eFSE predicted whether or not an individual animal developed spontaneous seizures that involved, and seem to originate from, the hippocampus (Choy et al., 2014). Here we capitalized on the epilepsy-predicting MRI signal change, and studied whether augmented expression of hippocampal cytokines in individual rats correlated in the same animal with reduced T2 values. In this cohort, MRI T2 relaxation time was reduced in a subset of eFSE rats $6 \mathrm{~h}$ after insult compared with controls (Fig. 7A). Three of six eFSE rats in this cohort had T2 relaxation times that were lower than 2 SDs from the control mean, the cutoff for considering the signal abnormal and predictive of epilepsy in later life (Fig. $7 B$ ). We assessed hippocampal cytokine expression in the same rats $24 \mathrm{~h}$ after eFSE. The expression of a number of inflammatory mediators tended to be higher in the rats in which MRI signal changes were found (Fig. 7C). In addition, the expression of a number of individual inflammatory mediators correlated significantly and inversely with T2 relaxation times. This correlation was largely limited to inflammatory molecules that were up- regulated in hippocampus $24 \mathrm{~h}$ after the insult, including IL-1r1 and COX2 (Fig. 7D,E).

Because the epilepsy-predicting change in T2 relaxation time took place in the amygdala complex, we examined in an additional cohort of animals whether cytokine expression in the amygdala correlated with T2 signal changes in the same animal. In this cohort, 7 of 11 eFSE animals had T2 relaxation times lower than 2 SDs of control ("affected"; Fig. 7F). Amygdala cytokine mRNA levels at $24 \mathrm{~h}$ after eFSE are shown in Figure 7G, dividing the cohort into affected and nonaffected. As apparent, a subgroup of inflammatory mediators, including IL-1r1, TLR4, and IL-6, seemed to distinguish between the groups. When amygdalar cytokine mRNA levels were plotted against T2 relaxation times, only IL-1r1 was significantly correlated (Fig. $7 H$ ). Comparing the correlations of hippocampal and amygdala cytokine levels and the predictive T2 signal change, IL-1r1 was common to both regions. In addition, COX2 correlated with the MRI changes in hippocampus only. A weak correlation between mRNA levels of TLR4, a target of HMGB1 with MRI changes was observed $(p=0.15$, Spearman $r=-0.33$; Fig. 7I). Together, these data suggest that individual differences among rats in the type and degree of inflammatory response to eFSE in at least two limbic regions implicated in epileptogenesis may underlie MRI signal changes that predict the eventual development of epilepsy in the same rats. The data support the notion that specific subsets of inflammatory molecules contribute to epileptogenesis following eFSE in individual animals.

\section{Discussion}

The principal findings of this series of experiments are as follows: (1) rapid and coordinate upregulated expression of a subset of inflammatory molecules takes place in hippocampus and amygdala within hours after eFSE; (2) inflammatory mediator expression profiles vary significantly among individual rats experiencing eFSE, and only partial overlap exists between hippocampal and amygdala expression patterns; and (3) inflammatory pro- 
A
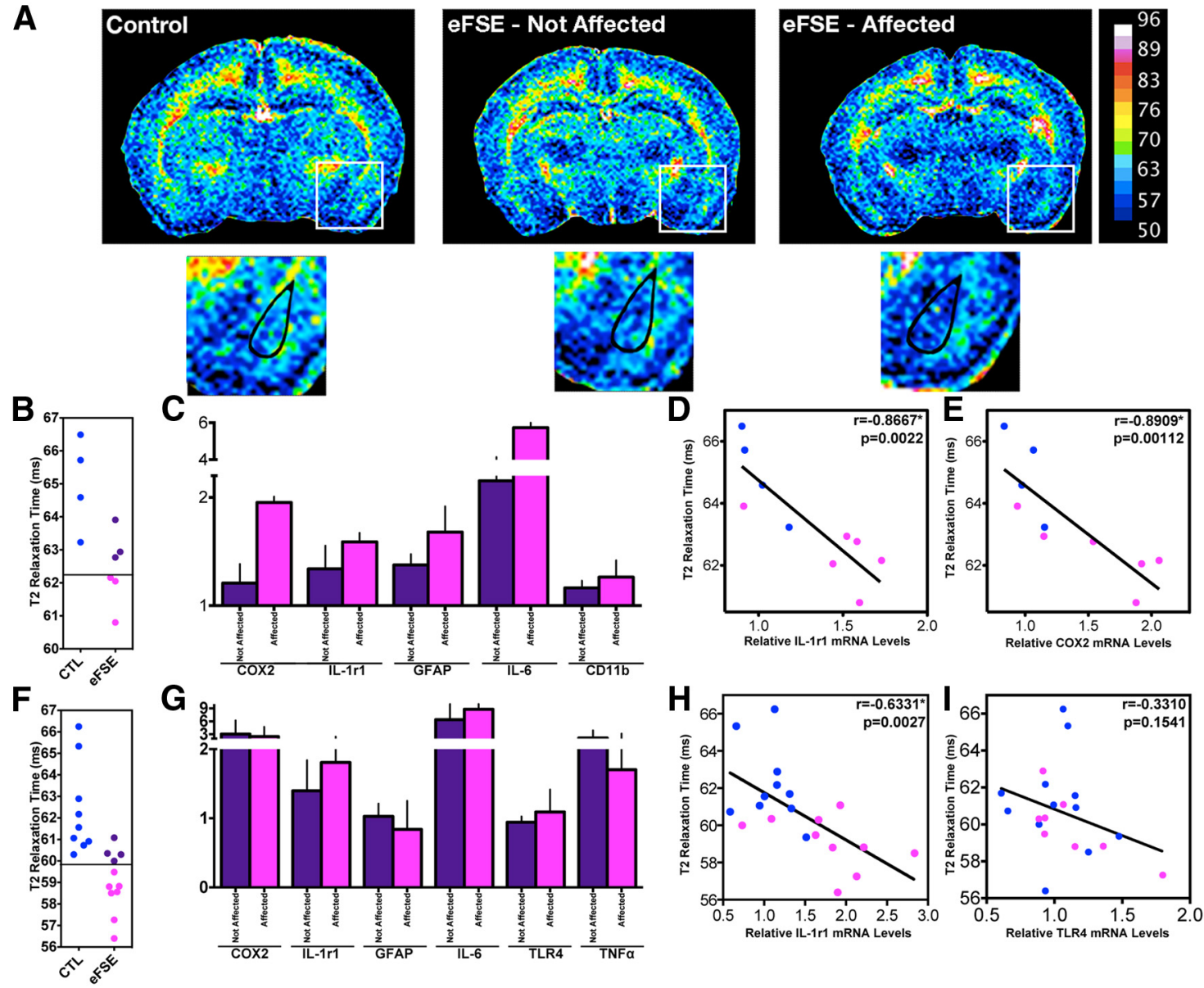

Figure 7. Inflammation profiles of individual animals correlate with predictive measures of post-eFSE epilepsy. A, Representative color-coded quantitative T2 maps 4-6 h after the end of eFSE from a control animal $(n=9)$, an eFSE animal not expected to become epileptic (eFSE-Not Affected; $n=5$ ), and an eFSE animal expected to become epileptic (eFSE-Affected; $n=7$ ). Basolateral amygdala (whose T2 relaxation time is used to predict epilepsy) is highlighted in enlarged pictures below. Cooler colors (blues) represent faster T2 relaxation times, while warmer colors (greens and oranges) indicate slower T2 relaxation times. B, Prediction of epilepsy after eFSE is determined when T2 relaxation times of eFSE fall 2 SDs below the control mean, represented here by a black line across the $y$-axis. $\boldsymbol{C}$, In hippocampus, the expression of inflammatory molecules is higher in animals expected to become epileptic (Affected) compared with those not expected to become epileptic (Not Affected). $\boldsymbol{D}, \boldsymbol{E}$, Inverse correlations are found between T2 relaxation times and IL-1r1 $(\boldsymbol{D})$ and COX2 (E; CTL, $n=4$, eFSE $n=6)$. $\boldsymbol{F}$, For cytokine correlations in amygdala, 7 of $11 \mathrm{eFSE}$ animals had T2 values low enough to consider them affected. G, Cytokine mRNA data from amygdalar punches $24 \mathrm{~h}$ after the end of eFSE demonstrate lower discrimination between affected and nonaffected animals. $\boldsymbol{H}, \boldsymbol{I}$, Correlations between predictive MRI signal changes were present with IL-1r1 mRNA $(\boldsymbol{H})$, and a weak correlation existed between T2 levels and TLR4 (l; CTL, $n=9$; eFSE, $n=12)$. Data are presented as the mean \pm SEM. $*$ Statistically significant at $p<0.05$. CTL, Control.

files of individual rats correlate with MRI T2 signal changes that predict epileptogenesis.

The earliest change detected in a subgroup of immature rats experiencing eFSE was the translocation of the cellular stress-sensitive protein HMGB1 from nucleus to cytoplasm (Rovere-Querini et al., 2004). This event, taking place within minutes to hours suggests that while eFSE does not seem to kill cells, it does provoke major cellular stress in hippocampal neurons (Toth et al., 1998; Dubé et al., 2010; Choy et al., 2014). HMGB1 translocation to the cytoplasm is typically followed by release from the cell and activation of receptors on microglia and astrocytes (including TLR4) to promote the synthesis of multiple inflammatory cytokines (Rovere-Querini et al., 2004). It should be noted that a number of other activators of TLR4 receptors (e.g., degradation products of the cellular matrix and heat shock proteins) have been reported by several groups. However, cellular debris and heat shock proteins have not been found in the eFSE model (Toth et al., 1998; Bender et al., 2004; Baram et al., 2011). In addition, whereas HMGB1 translocation in adult models of epilepsy has typically been reported in astrocytes and microglia (Maroso et al., 2010), in the eFSE model we find the translocation exclusively in neurons during the first few hours (Choy et al., 2014). This cell specificity might be a result of the seizure-inciting insult, the age of the animals, or both (Baram, 2012).

Here we found that, in hippocampus, the expression of $\mathrm{IL}-1 \beta$, its receptor (IL-1r1), TNF- $\alpha$, COX2, and GFAP were upregulated during the hours and days following eFSE. 
Most cytokines were transiently upregulated with levels resembling those in controls by $96 \mathrm{~h}$ after eFSE. Only COX2 remained upregulated at this time point. Looking within the amygdala (at the $24 \mathrm{~h}$ time point) demonstrated similar findings, with IL-6, COX2, and TNF- $\alpha$ expression augmented. These quantitative analyses of cytokine expression were complemented by immunohistochemical evidence for significant astrocytosis and microglia activation $24 \mathrm{~h}$ after eFSE, which is indicative of an active inflammatory response in the hippocampus. Thus, whereas the expression of the cytokines measured here was transient, it might well set in motion additional downstream processes, potentially via activation of NF- $\kappa \mathrm{B}$ and other transcriptional regulators (Crespel et al., 2002; Aronica et al., 2010). These downstream consequences of the original wave of select inflammatory processes might contribute to the development of epilepsy.

An important question for both clinical FSE and eFSE is why some individuals go on to have epilepsy while others do not. Whereas it is difficult to test in humans, we have tried to identify factors that might contribute to epilepsy during or after eFSE. There were no discernable differences in the initial eFSE, where the seizure duration, time to onset, and intensity were similar among rats that eventually became epileptic and those that did not (Dubé et al., 2010; Choy et al., 2014). As demonstrated here, it is unlikely that the hyperthermia alone caused toxic physiological consequences because core temperatures never elevated above $41.5^{\circ} \mathrm{C}$ during eFSE. In addition, whereas there was no interlitter variability in reaction to the inciting event, interanimal variability was found in each litter both in the expression of inflammatory mediators and in potential seizure outcome. The studies described here suggest that an insult across genetically similar animals might result in markedly varied inflammatory profiles. These might derive from prior inflammatory or immune challenge (Riazi et al., 2010; Galic et al., 2012) or other, as yet undiscovered, reasons. The current data tempt us to speculate that the divergent inflammatory responses in rats experiencing eFSE might, in turn, lead to divergent epileptogenic outcomes.

Interestingly, while in hippocampus both COX2 and IL-1r1 levels correlated with the epilepsy-predictive MRI signal change after eFSE, in amygdala the correlation was with IL-1r1 mRNA levels only. The divergence between regions may suggest regional inflammatory differences in the limbic system that are important for epileptogenesis. The involvement of IL-1r1 in both regions is intriguing, suggesting that this specific cytokine may be instrumental in epilepsy generated by eFSE. Previous work (Dubé et al., 2005) has demonstrated that this cytokine pathway was required for the generation of eFSE. Further work (Dubé et al., 2010) suggested that IL-1 $\beta$ levels distinguished adult epileptic rats from those that did not develop epilepsy following eFSE. The current work provides additional support for the notion that augmentation of this cascade in a subset of rats contributes to epileptogenesis in the same rats. Notably, blocking the interleukin-1 cascade in epileptic animals has anticonvulsive effects, but the role of this cascade in epileptogenesis is presently unclear (Maroso et al., 2011; Noe et al., 2013). This role might vary among models because of differences in animal ages and other parameters.

In summary, these correlative studies demonstrate a potential relationship between selective augmentation of subsets of inflammatory mediators after eFSE and epilepsy. Blocking inflammation as a whole (Holtman et al., 2014) has proven unhelpful for aborting epilepsy, as have a number of studies targeting specific pathways in the inflammatory molecular network (Holtman et al., 2009; Vezzani et al., 2011; Noe et al., 2013). Indeed, rather than being pathogenic, it is possible that some observed inflammatory responses may be neuroprotective against the epileptogenic process, as has been described for other disorders (Schwartz and Kipnis, 2005). Future studies will focus on dissecting out which of the inflammatory cytokines and mediators described here are epileptogenic and which might be important for restoring normal neuronal function.

\section{References}

Annegers JF, Hauser WA, Shirts SB, Kurland LT (1987) Factors prognostic of unprovoked seizures after febrile convulsions. $\mathrm{N}$ Engl J Med 316:493-498. CrossRef Medline

Aronica E, Fluiter K, Iyer A, Zurolo E, Vreijlin E, van Vliet EA, Baayen JC, Gorter JA (2010) Expression pattern of miR-146a, an inflammation-associated microRNA, in experimental and human temporal lobe epilepsy. Eur J Neurosci 31:1100-1107. CrossRef

Baram TZ (2012) The brain, seizures and epilepsy throughout life: understanding a moving target. Epilepsy Curr 12:7-12. CrossRef Medline

Baram TZ, Gerth A, Schultz L (1997) Febrile seizures: an appropriateaged model suitable for long-term studies. Dev Brain Res 98:265270. Medline

Baram TZ, Jensen FE, Brooks-Kayal A (2011) Does acquired epileptogenesis in the immature brain require neuronal death? Epilepsy Curr 11:21-26. Medline

Bender RA, Dubé C, Baram TZ (2004) Febrile seizures and mechanisms of epileptogenesis: insights from an animal model. Adv Exp Med Biol 548:213-225. Medline

Berg AT, Shinnar S (1996) Complex febrile seizures. Epilepsia 37: 126-133. Medline

Berg AT, Shinnar S, Darefsky AS, Holford TR, Shapiro ED, Salomon ME, Crain EF, Hauser AW (1997) Predictors of recurrent febrile seizures: a prospective cohort study. Arch Pediatr Adolesc Med 151:371-378. Medline

Bianchi ME, Manfredi AA (2007) HIgh mobility group box 1 (HMGB1) protein at the crossroads between innate and adaptive immunity. Immunological reviews 200(1): 35-46. CrossRef Medline

Cendes F, Andermann F, Dubeau F, Gloor P, Evans A, JonesGotman M, Olivier A, Andermann E, Robitaille Y, Lopes-Cendes I (1993) Early childhood prolonged febrile convulsions, atrophy and sclerosis of mesial structures, and temporal lobe epilepsy: an MRI volumetric study. Neurology 43:1083-1087.

Choy, M, Dubé, CM, Patterson KP, Barnes SR, Maras P, Blood A B, Hasso An, Obenaus A, Baram TZ (2014) A novel, noninvasive, predictive epilepsy biomarker with clinical potential. J Neurosci 34:8672-8684. CrossRef Medline

Crespel A, Coubes P, Rousset MC, Brana C, Rougier A, Rondouin G, Bockaert J, Baldy-Moulinier M, Lerner-Natoli M (2002) Inflammatory reactions in human medial temporal lobe epilepsy with hippocampal sclerosis. Brain Res 952:159-169. Medline

Dedeurwerdere S, Friedman A, Fabene PF, Mazarati A, Murashima YL, Vezzani A, Baram TZ (2012) Finding a better drug for epilepsy: antiinflammatory targets. Epilepsia 53:1113-1116.

De Simoni MG, Perego C, Ravizza T, Moneta D, Conti M, Marchesi F, De Luigi, A, Garattini S, Vezzani A (2000) Inflammatory cytokines and related genes are induced in the rat hippocampus by limbic status epilepticus. Eur J Neurosci 12:2623-2633. Medline 
Dubé, C, Chen K, Eghbal-Ahmadi M, Brunson K, Soltesz I, Baram TZ (2000) Prolonged febrile seizures in the immature rat model enhance hippocampal excitability long term. Ann Neurol 47:336-344. Medline

Dubé C, Yu H, Nalcioglu O, Baram TZ (2004) Serial MRI after experimental febrile seizures: altered T2 signal without neuronal death. Ann Neurol 56:709-714. CrossRef Medline

Dubé C, Vezzani A, Behrens M, Bartfai T, Baram TZ (2005) Interleukin-1beta contributes to the generation of experimental febrile seizures. Ann Neurol 57:152-155. CrossRef Medline

Dubé CM, Brewster AL, Richichi C, Zha Q, Baram TZ (2007) Fever, febrile seizures and epilepsy. Trends Neurosci 30:490-496. CrossRef Medline

Dubé CM, Zhou JL, Hamamura M, Zhao Q, Ring A, Abrahams J, McIntyre K, Nalcioglu O, Shatskih T, Baram TZ, Holmes GL (2009a) Cognitive dysfunction after experimental febrile seizures. Exp Neurol 215:167-177. CrossRef Medline

Dubé CM, Brewster AL, Baram TZ (2009b) Febrile seizures: mechanisms and relationship to epilepsy. Brain Dev 31:366-371. CrossRef Medline

Dubé CM, Ravizza T, Hamamura M, Zha Q, Keebaugh A, Fok K, Andres AL, Nalcioglu O, Obenaus A, Vezzani A, Baram TZ (2010) Epileptogenesis provoked by prolonged experimental febrile seizures: mechanisms and biomarkers. J Neurosci 30:7484-7494. CrossRef Medline

Eskilsson A, Mirrasekhian E, Dufour S (2014) Immune-induced fever is mediated by IL-6 receptors on brain endothelial cells coupled to STAT3-dependent induction of brain endothelial prostaglandin synthesis. J Neurosci 34:15957-15961. CrossRef Medline

French JA, Williamson PD, Thadani VM, Darcey TM, Mattson RH, Spencer SS, Spencer DD (1993) Characteristics of medial temporal lobe epilepsy: I. Results of history and physical examination. Ann Neurol 34:774-780. CrossRef Medline

Galic MA, Riazi K, Pittman QJ (2012) Cytokines and brain excitability. Front Neuroendocrinol 33:116-125. CrossRef Medline

Heida JG, Pittman QJ (2005) Causal links between brain cytokines and experimental febrile convulsions in the rat. Epilepsia 46:19061913. CrossRef Medline

Heida JG, Boissé L, Pittman QJ (2004) Lipopolysaccharide- induced febrile convulsions in the rat: short-term sequelae. Epilepsia 45: 1317-1329. CrossRef Medline

Heida JG, Teskey GC, Pittman QJ (2005) Febrile convulsions induced by the combination of lipopolysaccharide and low-dose kainic acid enhance seizure susceptibility, not epileptogenesis, in rats. Epilepsia 46:1898-1905. CrossRef

Heida JG, Moshé SL, Pittman QJ (2009) The role of interleukin-1 $\beta$ in febrile seizures. Brain Dev 388-393. CrossRef

Hellier JL, Patrylo PR, Buckmaster PS, Dudek FE (1998) Recurrent spontaneous motor seizures after repeated low-dose systemic treatment with kainate: assessment of a rat model of temporal lobe epilepsy. Epilepsy Res 31:73-84. CrossRef

Holtman L, van Vliet EA, van Schaik R, Queiroz CM, Aronica E, Gorter JA (2009) Effects of SC58236, a selective COX-2 inhibitor, on epileptogenesis and spontaneous seizures in a rat model for temporal lobe epilepsy. Epilepsy Res 84:56-66. CrossRef Medline

Holtman L, van Vliet EA, Edelbroek PM, Aronica E, Gorter JA (2010) Cox-2 inhibition can lead to adverse effects in a rat model for temporal lobe epilepsy. Epilepsy Res 91:49-56. CrossRef Medline

Holtman L, van Vliet EA, Appeldoorn C, Gaillard PJ, de Boer M, Dorland R, Wadman WJ, Gorter JA (2014) Glutathione pegylated liposomal methylprednisolone administration after the early phase of status epilepticus did not modify epileptogenesis in the rat. Epilepsy Res 108:396-404. CrossRef

Jansen JFA, Lemmens EMP, Strijkers GJ, Prompers JJ, Schijns OEMG, Kooi ME, Beuls EAM, Nicolay K, Backes WH, Hoogland G (2008) Short- and long-term limbic abnormalities after experimental febrile seizures. Neurobiol Dis 32:293-301. CrossRef Medline
Lenz KM, Nugent BM, Haliyur R, McCarthy MM (2013) Microglia are essential to masculinization of brain and behavior. J Neurosci 33:2761-2772. CrossRef Medline

Lewis DV, Shinnar S, Hesdorffer DC (2014) Hippocampal sclerosis after febrile status epilepticus: the FEBSTAT study. Ann Neurol 75:178-185. CrossRef Medline

Luheshi GN, Stefferl A, Turnbull AV (1997) Febrile response to tissue inflammation involves both peripheral and brain IL-1 and TNFalpha in the rat. Am J Physiol 272:R862-R868. Medline

Maroso M, Balosso S, Ravizza T, Liu J, Aronica, E, lyer A. M, Rossetti, C, Molteni M, Casalgrandi M, Manfredi AA, Bianchi ME, Vezzani A (2010) Toll-like receptor 4 and high-mobility group box-1 are involved in ictogenesis and can be targeted to reduce seizures. Nat Med 16:413-419. CrossRef Medline

Maroso M, Balosso S, Ravizza T, lori V, Wright Cl, French J, Vezzani A (2011) Interleukin-1 biosynthesis inhibition reduces acute seizures and drug resistant chronic epileptic activity in mice. Neurotherapeutics 8:304-315. CrossRef Medline

Noe FM, Polascheck N, Frigerio F, Bankstahl M, Ravizza T, Marchini S, Beltrame L, Reschke Banderó C, Löscher W, Vezzani A (2013) Pharmacological blockade of IL-1 $\beta / \mathrm{IL}-1$ receptor type 1 axis during epileptogenesis provides neuroprotection in two rat models of temporal lobe epilepsy. Neurobiol Dis 59:183-193. CrossRef

Ollikainen J, Honkaniemi J, Palmio J, Peltola J (2004) Regulation of IL-6 system in cerebrospinal fluid and serum compartments by seizures: the effect of seizure type and duration. J Neuroimmunol 152:121-125. CrossRef Medline

Patterson KP, Baram TZ, Shinnar S (2014) Origins of temporal lobe epilepsy: febrile seizures and febrile status epilepticus. Neurotherapeutics 11:242-250. CrossRef Medline

Pouliot WA, Dudek FE, Dingledine R (2013) Inhibition of the prostaglandin receptor EP2 following status epilepticus reduces delayed mortality and brain inflammation. Proc Natl Acad Sci U S A 110: 3591-3596.

Ravizza T, Gagliardi B, Francesco N, Boer K, Aronica E, Vezzani A (2008) Innate and adaptive immunity during epileptogenesis and spontaneous seizures: evidence from experimental models and human temporal lobe epilepsy. Neurobiol Dis 29:142-160. CrossRef

Riazi K, Galic MA, Pittman QJ (2010) Contributions of peripheral inflammation to seizure susceptibility: cytokines and brain excitability. Epilepsy Res 89:34-42. CrossRef Medline

Rovere-Querini P, Capobianco A, Scaffidi P, Valentinis B, Catalanotti F, Giazzon M, Dumitriu IE, Müller S, lannacone M, Traversari C, Bianchi ME, Manfredi AA (2004) HMGB1 is an endogenous immune adjuvant released by necrotic cells. EMBO Rep 5:825-830. CrossRef Medline

Schwartz M, Kipnis J (2005) Protective autoimmunity and neuroprotection in inflammatory and noninflammatory neurodegenerative diseases. J Neurol Sci 233:163-166. CrossRef Medline

Scott RC, Gadian DG, King MD, Chong WK, Cox TC (2002). Magnetic resonance imaging findings within 5 days of status epilepticus in childhood. Brain 125:1951-1959. Medline

Seinfeld S, Shinnar S, Sun S, Hesdorffer DC, Deng X, Shinnar RC, O'Hara K, Nordli DR, Frank LM, Gallentine, W, Moshé SL, Pellock JM (2014) Emergency management of febrile status epilepticus: results of the FEBSTAT study. Epilepsia 55:388-395. CrossRef Medline

Toth Z, Yan XX, Haftoglou, Ribak CE, Baram TZ (1998) Seizureinduced neuronal injury: vulnerability to febrile seizures in an immature rat model. J Neurosci 18:4285-4294. Medline [Mismatch]

VanLandingham KE, Heinz RE, Cavazos JE, Lewis DV (1998). Magnetic resonance imaging evidence of hippocampal injury after prolonged focal febrile convulsions. Ann Neurol 43:413-426. CrossRef Medline

Vezzani A, Balosso S, Ravizza T (2008) The role of cytokines in the pathophysiology of epilepsy. Brain 22:797-803. CrossRef Medline

Vezzani A, French J, Bartfai T, Baram TZ (2011) The role of inflammation in epilepsy. Nat Rev Neurol 7:31-40. CrossRef Medline 